\title{
ANALISIS PERBANDINGAN METODE WEIGHTED PRODUCT (WP) DENGAN METODE SIMPLE ADDITIVE WEIGHTING (SAW) UNTUK PENDUKUNG KEPUTUSAN PEMILIHAN BIRO PERJALANAN PARIWISATA
}

\author{
Ryzal Pradito, Yuliani Indrianingsih \\ Jurusan Teknik Informatika \\ Sekolah Tinggi Teknologi Adisutjipto Yogyakarta \\ informatika@stta.ac.id
}

\begin{abstract}
Decision Support System (DSS) is a system that helps managers to solve a semi-structured problem. There are techniques used to make the DSS, one of them is Fuzzy Logic Multi Criteria Decission Makaing (MCDM). Weigthed Product Method (WP) and Single Additive Weighting Method (SAW) is a method to solve the problem using multiplication to connect the atribute ratings, where rating attributes must be raised first with the weight relevant attributes weights. The applications results show comparison WP methods and SAW methods is closer to the value 1, so that the SAW method is the most appropriate method to solve the problem of the selection a troel agency tourism.
\end{abstract}

Keywords : SPK, SAW method, WP method

\section{Pendahuluan}

Penentuan pemilihan biro perjalanan bis pariwisata memiliki banyak pertimbangan untuk dipikirkan. Banyak aspek yang perlu diperhitungkan karena menyangkut pelayanan terhadap banyak orang sebagai pengguna jasa. Dalam menentukan pilihan terkadang pengguna kebingunan harus menilai penyedia jasa biro perjalanan pariwisata dari aspek apa saja, standar penilaian dan kriteria yang tidak jelas seperti inilah yang akan membingungkan para pengguna jasa tersebut.

Oleh karena itu perlu dibangun sebuah sistem pendukung keputusan (decision support system ) yang akan membantu penentuan siapa yang layak untuk mendapatkan bantuan. Model yang digunakan dalam sistem pendukung keputusan adalah Fuzzy Criteria Attribute Decision Making (FMCDM). Untuk melakukan perhitungan metode FMCDM pada masalah ini ditentukan dengan membandingkan metode WP (Weigthed Product)dengan metode SAW (Simple Addtive Weighting). Harapannya sistem tersebutdapatmembantu atau memudahkan pengambilan keputusan dalam hal penentuan pemilhan biro perjalanan pariwisata. Sehingga akan di dapatkan biro perjalanan pariwisata yang paling layak dan memenuhi kriteria perjalanan wisata.

\section{METODOLOGI}

\subsection{Metode WP}

Metode weighted product merupakan salah satu metode penyelesaian yang di tawarkan untuk menyelesaikan masalah Multi Atribute Decission Making (MADM). Metode WP mirip 
dengan metode Weighted Sum (WS), hanya saja metode WP terdapat perkalian perhitungan matematiknya. Metode WP juga di sebut analisis berdimensi karena struktur matematikanya menghilangkan satu ukuran. Metode WP adalah himpunan berhingga dari alternatif keputusan yang di jelaskan dalam beberapa hal kriteria keputusan. Jadi metode ini tidak perlu di normalisasikan.

a. Rumus melakukakn perbaikan bobot :

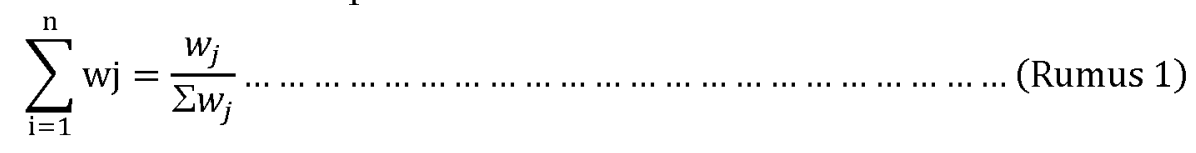

b. Rumus perhitungan vektor $S$ :

$$
S i=\prod_{j=1}^{n} X i j w j ; \text { dengan } \mathrm{i}=1,2, \ldots, \mathrm{m} \ldots \ldots \ldots \ldots \ldots \ldots \ldots \ldots(\text { Rumus } 2)
$$

\subsection{Metode SAW}

Metode SAW sering juga dikenal istilah metode penjumlahan terbobot. Konsep dasar metode SAW adalah mencari penjumlahan terbobot dari rating kinerja pada setiap alternatif pada semua atribut. Metode SAW membutuhkan proses normalisasi matriks keputusan $(X)$ ke suatu skala yang dapat diperbandingkan dengan semua rating alternatif yang ada.

a. Rumus normalisasi matriks

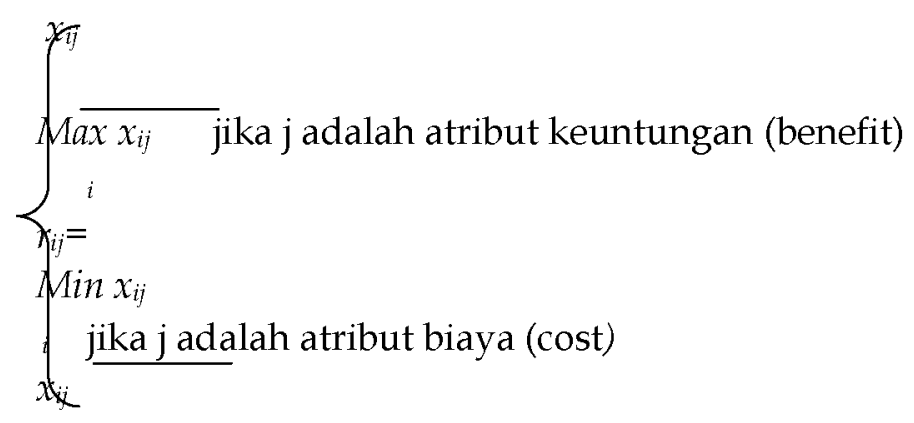
(rumus 3)

b. Rumus perhitungan rangking

$$
V_{i}=\sum_{j=1}^{n} w_{j} r_{i j}
$$

\subsection{Perancangan Aplikasi}

\subsubsection{Diagram Konteks}

Pada diagram konteks yang ditunjukkan pada Gambar 1 akan menjelaskan entitas entitas yang terlibat, dan aliran data secara garis besar.Sehingga dapat dilihat secara keseluruhan input ke sistem atau output dari sistem. Dengan adanya diagram konteks ini dpat diketahui untuk perancangan proses selanjutnya. Untuk aplikasi sistem pendukung keputusan dalam menentukan pemilihan biro perjalanan pariwisata ini yang terlibat didalam sistem adalah user atau pengguna program. 

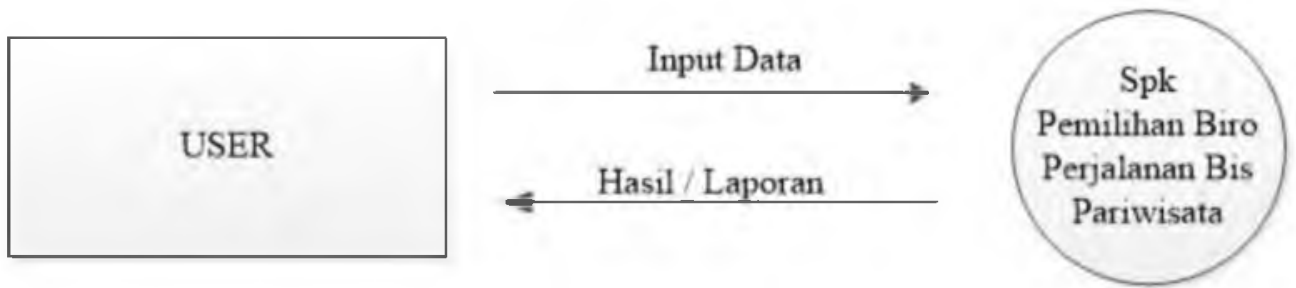

Gambar 1 Diagram Konteks SPK Pemilihan Biro Perjalanan Pariwisata

\subsubsection{DFD Level 1}

Diagram ini merupakan gambaran rinci dari proses yang dilakukan pada diagram konteks yang hanya menjelaskan secara umum proses yang dikerjakan oleh aplikasi. Proses tersebut digambarkan seperti pada Gambar 2.

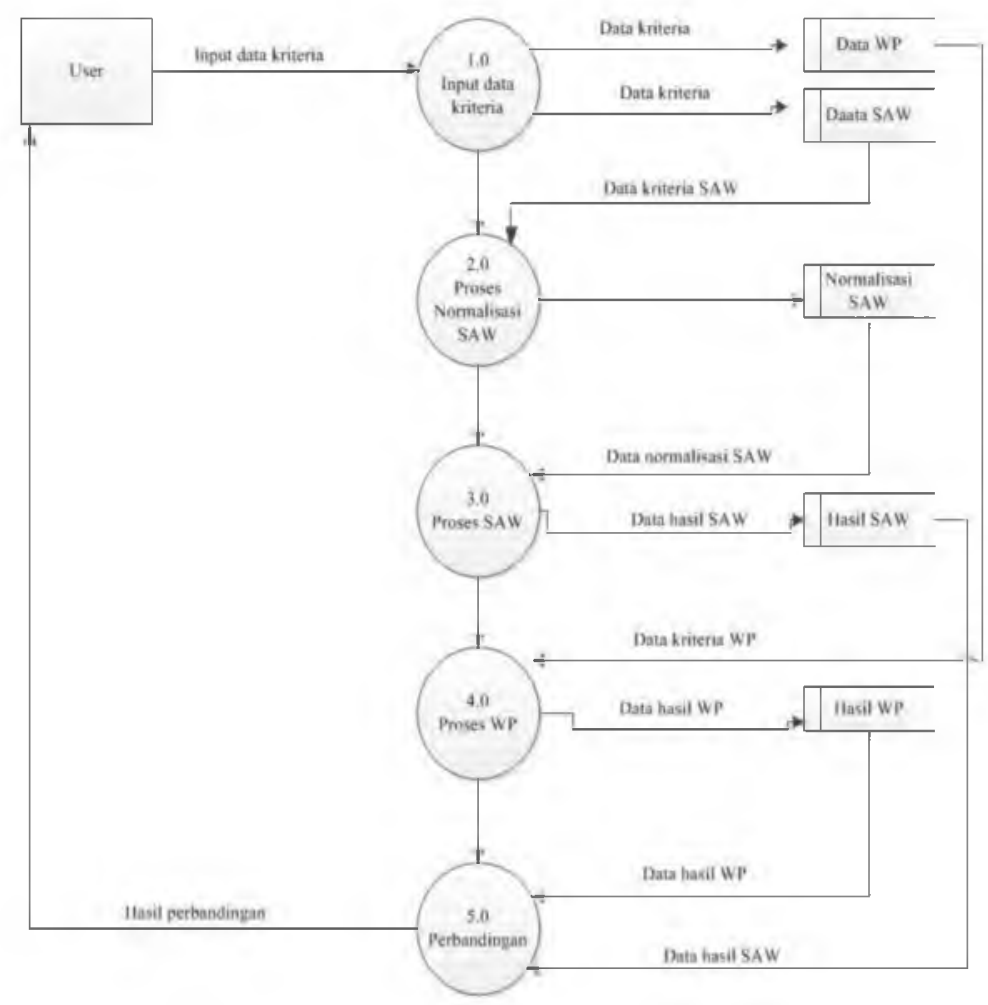

Gambar 2 DAD Level 1

Pada diagram alir data level 1 pada proses 1.0 pengguna atau user memasukan data kriteria, pada proses 2.0 pengguna melakukan proses normalisasi data kriteria untuk metode $S A W$, data yang telah dimasukkan kemudian disimpan untuk dipanggil lagi pada saat penilaian pada proses 3.0 dan 4.0 kemudian hasil perhitungan dibandingkan untuk memperoleh hasil akhir berupa nilai dan ranking pada proses ke 5.0.

\subsubsection{Flowchart Sistem}

Dalam membangun sistem diperlukan flowchart untuk melihat gambaran bagaimana proses dari sistem itu bekerja dari awal hingga selesai, hal ini dimaksudkan agar mengurangi kesalahan yang terjadi jika tidak memiliki acuan dalam rancangan. Sistem ini juga memilik alur data seperti yang ditunjukkan pada Gambar 3. 


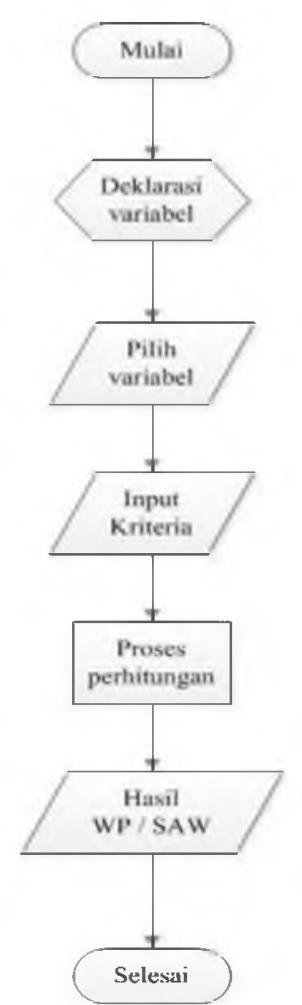

Gambar 3 Flowchart Sistem

\section{Hasil dan Pembahasan}

\subsection{Penjelasan Aplikasi}

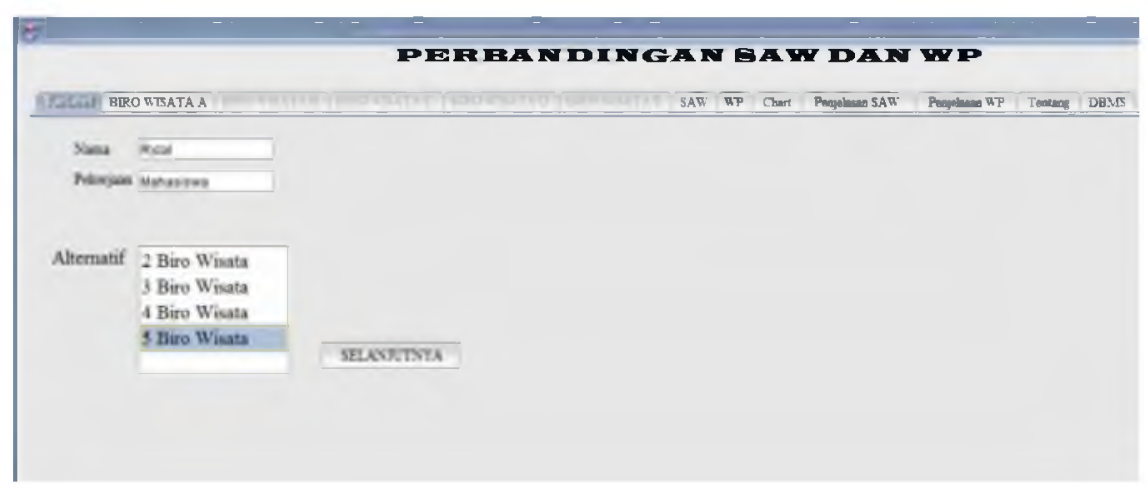

Gambar 4 Menu Utama SPK Pemilihan Biro Pejalanan Pariwisata

Tampilan halaman menu utama adalah tampilan pertama pada saat pengguna menjalankan aplikasi ini. Pada menu utama pengguna diminta untuk memilih berapa perbandingan yang akan dilakukan. Setelah memilih jumlah perbandingan yang diinginkanPada halaman menu biro wisata adalah kelanjutan dari proses input data perbandingan yang telah dilakukan pada halaman utama. Jumlah wisata yang akan dinilai sesuai dengan jumlah perbandingan yang dipilih. 


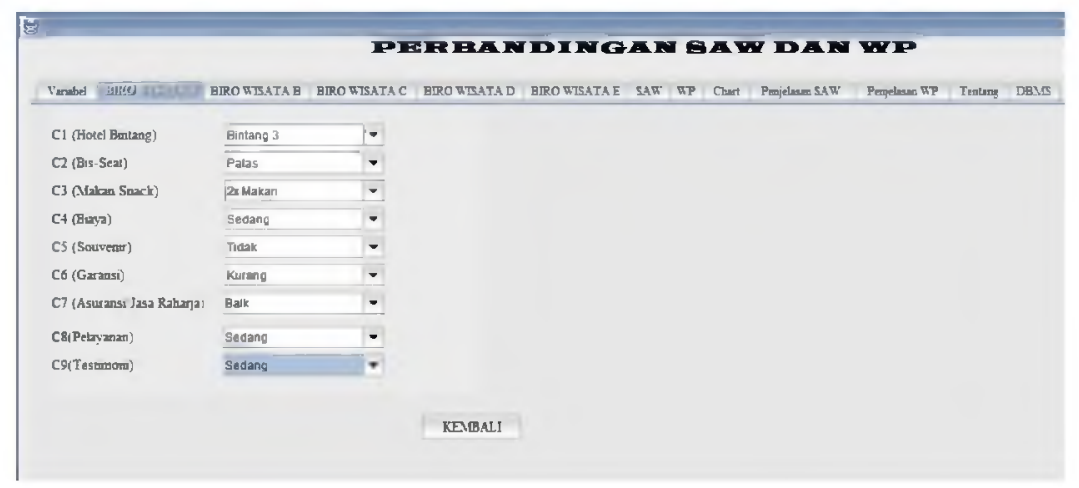

Gambar 5 Menu Biro Wisata SPK Pemilihan Biro Pejalanan Pariwisata

Pada halaman tampilan perhitungan metode menampilkan data-data yang telah diinput-kan berdasarkan kriterianya, lihat gambar 6. Pada halaman menu ini menunjukan hasil perhitungan perbadingan metode SAW dengan metode WP, lihat gambar7.

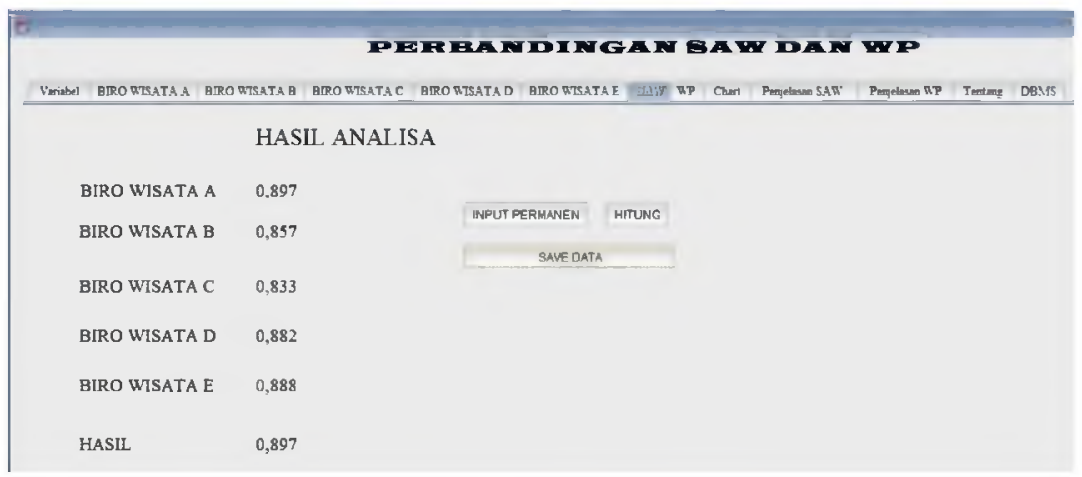

Gambar 6 Menu Perhitungan Metode SPK Pemilihan Biro Pejalanan Pariwisata

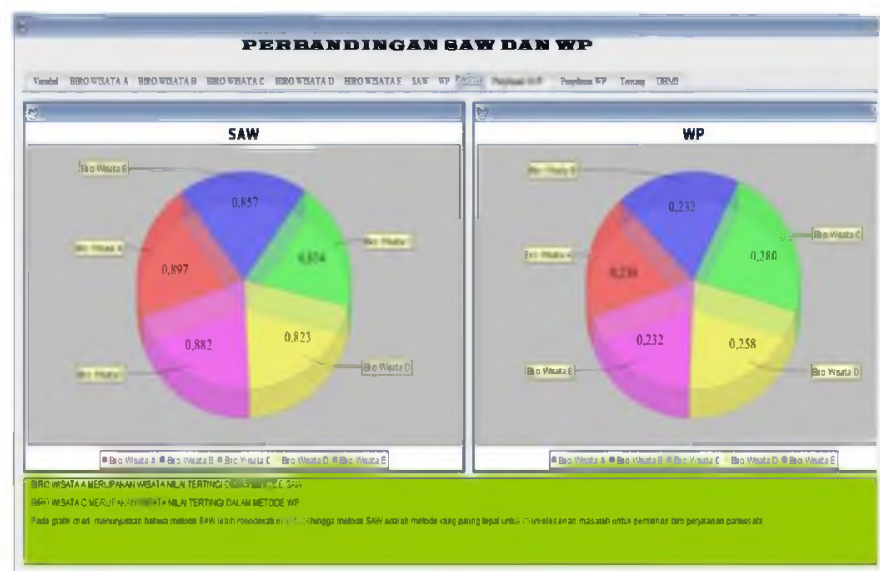

Gambar 7 Hasil Perbadingan Metode SAW dengan Metode WP

\subsection{Pembahasan}

Dari hasil penghitungan manual dengan menggunakan metode SAW dan WP dapat diketahui dan dilihat pada tabel 1 dan tabel 2. Sedangkan hasil perhitungan dengan menggunakan aplikasi yang dibuat dan dirancang dapat dilihat pada gambar 8 . 
Tabel 1 Perbadingan Hasil Perihitungan Metode SAW

\begin{tabular}{|c|c|c|c|}
\hline No & Nama & $\begin{array}{c}\text { Perhitungan } \\
\text { Manual }\end{array}$ & $\begin{array}{c}\text { Perhitungan } \\
\text { Sistem }\end{array}$ \\
\hline 1 & Biro Wisata A & 0.897 & 0.897 \\
\hline 2 & Biro Wisata E & 0.882 & 0.882 \\
\hline 3 & Biro Wisata B & 0.857 & 0.857 \\
\hline 4 & Biro Wisata C & 0.834 & 0.834 \\
\hline 5 & Biro Wisata D & 0.823 & 0.823 \\
\hline
\end{tabular}

Tabel 2 Perbadingan Hasil Perihtungan Metode WP

\begin{tabular}{|c|c|c|c|}
\hline No & Nama & $\begin{array}{c}\text { Perhitungan } \\
\text { Manual }\end{array}$ & $\begin{array}{c}\text { Perhitungan } \\
\text { Sistem }\end{array}$ \\
\hline 1 & Biro Wisata C & 0.280 & 0.280 \\
\hline 2 & Biro Wisata D & 0.258 & 0.258 \\
\hline 3 & Biro Wisata B & 0.232 & 0.232 \\
\hline 4 & Biro Wisata E & 0.232 & 0.232 \\
\hline 5 & Biro Wisata A & 0.230 & 0.230 \\
\hline
\end{tabular}

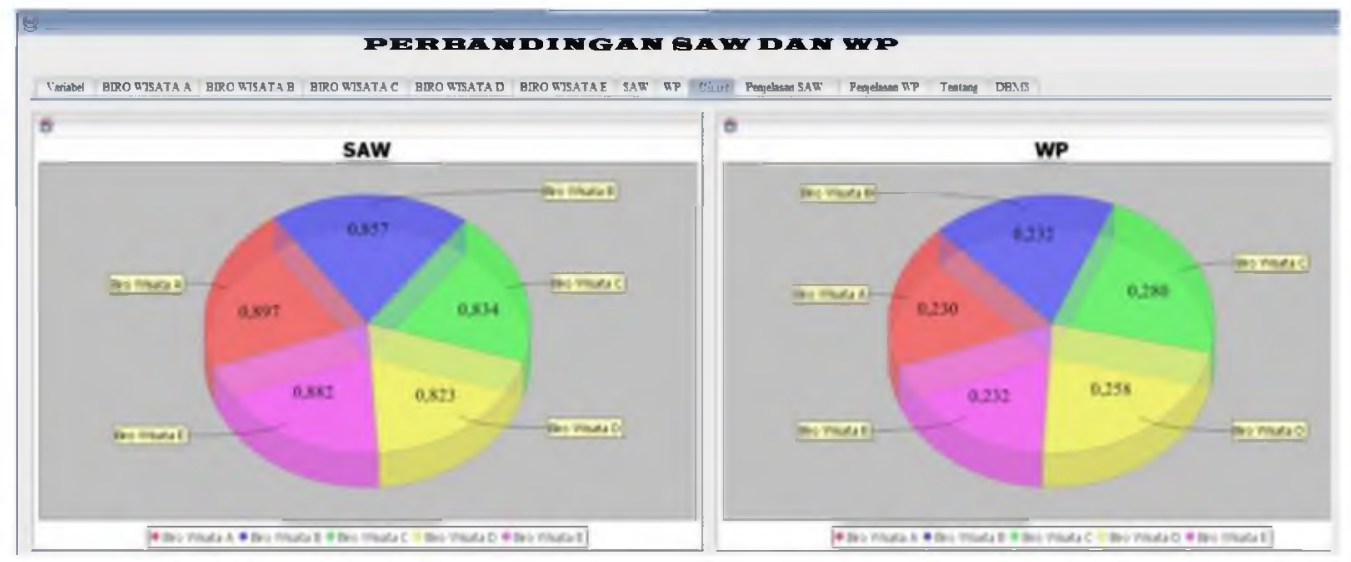

Gambar 8 Hasil Perbadingan Metode SAW dengan Metode WP

\section{Penutup}

\subsection{Kesimpulan}

Kesimpulan yang diperoleh dari penelitian yang telah dilakukan adalah :

1. Sistem pendukung keputusan pemilihan biro perjalanan pariwisata merupakan solusi bagi para konsumen untuk pemilihan biro perjalanan pariwisata sesuai dengan yang di inginkan.

2. Metode Weighted Product (WP) dan Metode Simple Additive Weighting (SAW)dapat diterapkan dalam sistem pendukung keputusan untuk pemilihan biro perjalanan pariwisata dan menghasilkan nilai yang sama antara perhitungan manual dan perhitungan sistem.

3. Hasil akhir perbandingan metode WP dan SAW pada sistem berupa perangkingan nilai tertinggi ke nilai terendah. Nilai tertinggi menempati prioritas utama untuk pemilihan biro perjalanan pariwisata. Hasil urutan perankingan antar kedua metode terkadang tidak selalu sama. 
4. Perbedaan hasil urutan perankingan tersebut karena metode SAW dan metode WP yang merupakan bagian dari model MCDM,sehingga mengandung unsur ketidakpastian atau kabur.

5. Perbandingan metode WP dan metode SAW pada grafik menunjukkan bahwa metode SAW lebih mendekati nilai 1, sehingga metode SAW adalah metode yang paling tepat untuk menyelesaikan masalah untuk pemilihan biro perjalanan pariwisata.

\subsection{Saran}

Saran untuk penelitian selanjutnya berdasarkan hasil penelitian ini adalah

1. Sistem perlu dibandingkan lagi menggunakan metode perangkingan yang berbeda pola algoritmanya sehingga dapat diketahui kinerjanya.

2. Tampilan atau Antarmuka pada sistem dibuat lebih menarik lagi untuk kedepannya sehingga admin dan user tidak merasa jenuh dalam penggunaan sistem ini.

Sistem ini dapat dikembangkan dengan platform lain berbasis smartphone khususnya Android.

\section{Daftar Pustaka}

Eko Dian, Cahyono Sigit Pramudyo, Arya Wirabhuana. 2012, Perancangan Sistem Pendukung keputusan Untuk Pemasok Nata De Coco (Studi Kasus di CV. Agrindo Suprafood Yogyakarta). ISSN cetak: 2302-691X

Jogianto, HM. 2005, Analisis dan Desain Sistem Informasi, Yogyakarta : Andi Offset

Kusrini. 2007, Konsep dan Aplikasi Sistem pendukung Keputusan, Yogyakarta : CV. Andi Offset

Kusuma, Dewi. 2006, Fuzzy Multi-Attribute Decission Making, Yogyakarta : Graha Ilmu

Maulana, Much. Rifqi. 2012, Penilaian Kinerja Karyawan Di IFUN Jaya Textile Dengan Metode Fuzzy Simple Additive Weighted. Jurnal Ilmiah ICTech Vol.x, No.1, Januari

Turban, E, Aronson J.E, dkk. 2003, Decission Support System and Intelligent System

(Sistem Pendukung Keputusan dan Sistem Cerdas). Andi Offset. Yogyakarta

Uyun, Shofwatul. 2011, A Fuzzy Topsis Multiple-Attribute Decision Making for Scholarship Selection. Jurnal TELKOMNIKA, Vol.9, No.1, April, pp. 37-46. 
Ryzal Pradit, Yuliani Indrianingsih 